\title{
Evaluation of Clinical and Histopathologic/Direct Immunofluorescence Diagnosis in Autoimmune Vesiculobullous Dermatitis: Utility of Direct Immunofluorescence
}

\author{
Otoimmün Vezikülobüllöz Dermatitlerin Klinik ve Histopatolojik/ \\ Direkt İmmünflöresan Tanı Değerlendirmesi: \\ Direkt İmmünflöresansın Faydası
}

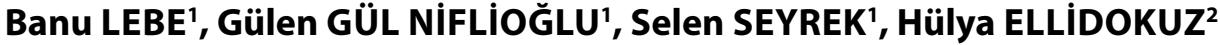 \\ Departments of ${ }^{1}$ Pathology and ${ }^{2}$ Biostatistics and Medical Informatics, Dokuz Eylül University, Faculty of Medicine, IZMiR, TURKEY
}

This article was presented as oral presentation at 19th National Pathology Congress, October 7-11, 2009 in Turkish Republic of Northern Cyprus.

\section{ABSTRACT}

Objective: Autoimmune bullous diseases are heterogeneous diseases and the differentiation between the various bullous disease is important for treatment and prognosis. Direct immunofluorescence microscopy is still the gold standard in differentiating these diseases. Our aim was to determine the diagnostic accordance between clinical and histopathological/direct immunofluorescence diagnosis of patients with autoimmune vesicolulobullous skin diseases.

Material and Method: A total of 197 cases with clinical diagnosis of vesiculobullous dermatitis was included in the study. The slides stained with $\mathrm{H} \& \mathrm{E}$ were retrospectively re-evaluated for histopathological diagnosis, and had already been evaluated with direct immunofluorescence microscopy. Data were analyzed using the Scientific Package for Social Sciences software. Results were evaluated using Kappa statistics.

Results: The clinical and histopathological/directimmunofluorescence accordance for cases ranged from $0 \%$ to $100 \%$ (Kappa value $=0.29$ ). The accordance was $58.8 \%$ in pemphigus vulgaris, $53.8 \%$ in pemphigus foliaceus, $37.9 \%$ in bullous pemphigoid and, $5.2 \%$ in dermatitis herpetiformis. Cases of limited numbers in our study were linear IgA bullous dermatitis in 2 cases, Grover's disease in 1 case, epidermolysis bullosa acquisata in 5 cases and, Hailey-Hailey disease in 1 case. The percentages of accordance in these cases were 50\%, 100\%, 40\% and, $0 \%$, respectively.

Conclusion: The accordance was good in pemphigus vulgaris, pemphigus foliaceus and bullous pemphigoid, but low in dermatitis herpetiformis. Based on our results, we recommend direct immunofluorescence microscopy to be added to light microscopy for the definitive diagnosis of autoimmune blistering disease. Only light microscopic findings are not sufficient and direct immunofluorescence microscopy is the gold standard.

Key Words: Fluorescent antibody technique, Direct, Vesiculobullous skin diseases

Received : 14.04 .2011

Accepted : 22.10.2011
ÖZ

Amaç: Otoimmün büllöz hastalıklar heterojen bir grup hastalıktır ve bu hastalıkların ayrımının yapılması tedavi ve prognoz için önemlidir. Direkt immünflöresan mikroskopi bu hastalıkların ayırıcı tanılarında hala altın standarttır. Bu çalışmanın amacı otoimmün vezikülobüllöz hastalıklarda klinik ve histopatolojik/direkt immünflöresan tanı uyumunu araştırmaktır.

Gereç ve Yöntem: Vezikülobüllöz dermatit tanısı almış toplam 197 olgu çalışmaya alındı. Olguların H\&E boyalı kesitleri tekrar gözden geçirilerek tanıları doğrulandı. Olguların direkt immünflöresan mikroskopi görüntüleri de fotoğraf arşivinden çıkartılarak tekrar gözden geçirildi. Veriler "Scientific Package for Social Sciences" yazılımı ile analiz edildi. Uyum kappa testi ile değerlendirildi

Bulgular: Olgularımızdaki klinik ve histopatolojik/direkt immünflöresan tanı uyumu \%0 ile \%100 arasında değişmekteydi (Kappa değeri=0.29). Uyum oranları pemfigus vulgariste $\% 58,8$, pemfigus foliaseusta $\% 53,8$, büllöz pemfigoidde $\% 37,9$ ve dermatitis herpetiformiste \%5,2 idi. Çalışmamızda sınırlı sayıdaki olgular 2 lineer IgA büllöz dermatiti, 1 Grover hastalığ 1 , 5 epidermolysis bullosa acquisata ve 1 Hailey-Hailey hastalığıydı. Bu olgulardaki uyum oranları sırasıyla $\% 50, \% 100, \% 40$ ve $\% 0$ 'd.

Sonuç: Pemfigus vulgaris, pemfigus foliaseus ve büllöz pemfigoid olgularında iyi uyum olmasına karşın, dermatitis herpetiformiste bu uyum düşüktü. Bulgularımıza dayanarak otoimmün büllöz hastalıkların kesin tanısı için 1şık mikroskopik incelemeye ek olarak direkt immünflöresan mikroskopiyi öneriyoruz. Sadece 1 şık mikroskopik bulgular kesin tanı için yeterli olmamaktadır ve direkt immünflöresan altın standarttır.

Anahtar Sözcükler: Floresan antikor tekniği, Direkt, Vezikülobüllöz deri hastalıkları

Correspondence: Banu LEBE

Department of Pathology, Dokuz Eylül University, Faculty of Medicine, İMIIR, TURKEY

E-mail: banu.lebe@deu.edu.tr Phone: +90 2324123412 


\section{INTRODUCTION}

Many skin diseases may present as vesicles or bullae. Autoimmune bullous diseases are a heterogeneous group and the differentiation between the various bullous diseases is important for treatment and prognosis. For autoimmune bullous diseases, only light microscopic findings or observations are not sufficient for definitive diagnosis. Direct immunofluorescence (DIF) using patient tissue or indirect immunofluorescence (IIF) studies using patient serum, or both may be required for diagnostic confirmation (1). DIF microscopy is still the gold standard in differentiating vesiculobullous diseases $(2,3)$. Immunofluorescent patterns are also significant in differentiating pemphigus group, bullous pemphigoid, dermatitis herpetiformis, linear IgA bullous dermatosis (LIGA), epidermolysis bullosa acquisata and Hailey-Hailey disease (1).

The aim of this study was to analyze the diagnostic accordance between clinical and histopathological/DIF diagnosis of patients with vesicolulobullous skin diseases diagnosed at Dokuz Eylül University, School of Medicine, Department of Pathology between May 2005 and May 2009.

\section{MATERIAL and METHODS}

A total of 197 cases with clinical diagnosis as vesiculobullous dermatitis that had been diagnosed in our department between May 2005 and May 2009 were included in our study. Hailey-Hailey $(\mathrm{HH})$ disease cases were included in our study because $\mathrm{HH}$ is important in the differential diagnosis of pemphigus group. The clinical information of the cases were obtained from the pathology reports and patients files. All sections of study cases stained with $\mathrm{H} \& \mathrm{E}$ were retrospectively re-evaluated for histopathological diagnosis. The cases had already been evaluated with DIF.

Data were analyzed using Scientific Package for Social Sciences software (SPSS). Accordance between clinical diagnosis and histopathological/DIF diagnosis was evaluated using kappa ( $\kappa$ ) tests for the final diagnosis. For $\kappa$ values, the following interpretations were generally accepted: slight agreement, $\mathrm{k}=0.00-0.20$; fair agreement, $\mathrm{k}=0.21-0.40$; moderate agreement, $\mathrm{k}=0.41-0.60$; substantial agreement, $\mathrm{k}=0.61-0.80$; and almost perfect agreement, $\mathrm{k}=0.81-1.00$.

\section{RESULTS}

The age range of the cases was between 2 months and 89 years with mean value 54.34 years and with median value 56.00 years. There were a total of 197 cases with 99 females (50.3\%) and 98 males (49.7\%).

The clinical diagnosis of the cases were bullous pemphigoid (BP) in 66 cases (33.5\%), dermatitis herpetiformis (DH) in 58 cases (29.4\%), pemphigus vulgaris (PV) in 51 cases (26\%), pemphigus foliaceus (PF) in 13 cases $(6.6 \%)$, epidermolysis bullosa acquisata (EPB) in 5 cases $(2.5 \%)$, linear IgA bullous dermatitis in 2 cases (1\%), Grover's disease (GD) in 1 case (0.50\%), and, Hailey-Hailey disease in 1 case $(0.50 \%)$.

Overall accordance between the clinical diagnosis and histopathological/DIF diagnosis was $58.8 \%$ in PV, $53.8 \%$ in $\mathrm{PF}, 37.9 \%$ in BP and, $5.2 \%$ in DH (Table I).

Thirty of 51 cases with a clinical diagnosis of PV were diagnosed as PV (58.8\%) by histopathology and DIF microscopy. Histopathological examination revealed suprabasal clefting and significant acantholysis in epidermis and dermal perivascular lymphocytic infiltrate. By DIF microscopy, intercellular IgG and/or C3 deposition in the epidermis were observed in all PV cases (Figure 1A,B). The remaining 21 cases were diagnosed as nonspecific superficial perivascular dermatitis in 8 cases (15.7\%), pustular dermatitis in 5 cases $(9.8 \%)$, spongiotic dermatitis in 2 cases (3.9\%), drug eruption in 2 cases (3.9\%), lichen planus in 2 cases (3.9\%), discoid lupus erythematosus in 1 case $(2 \%)$ and, vasculitis in 1 case $(2 \%)$.

Table I: Clinical diagnosis and the percentages of accordance for all cases

\begin{tabular}{|l|c|c|c|}
\hline Clinical diagnosis & Number of cases (n) & Percentage of cases (\%) & Percentage of accordance (\%) \\
\hline Bullous pemphigoid & 66 & 33.5 & 37.9 \\
\hline Dermatitis herpetiformis & 58 & 29.4 & 5.2 \\
\hline Pemphigus vulgaris & 51 & 26 & 58.8 \\
\hline Pemphigus foliaceus & 13 & 6.6 & 53.8 \\
\hline Epidermolysis bullosa & 5 & 2.5 & 40 \\
\hline LIGA & 2 & 1 & 50 \\
\hline Grover's disease & 1 & 0.50 & 0 \\
\hline Hailey-Hailey disease & 1 & 0.50 & 0 \\
\hline TOTAL & 197 & 100 & \\
\hline
\end{tabular}



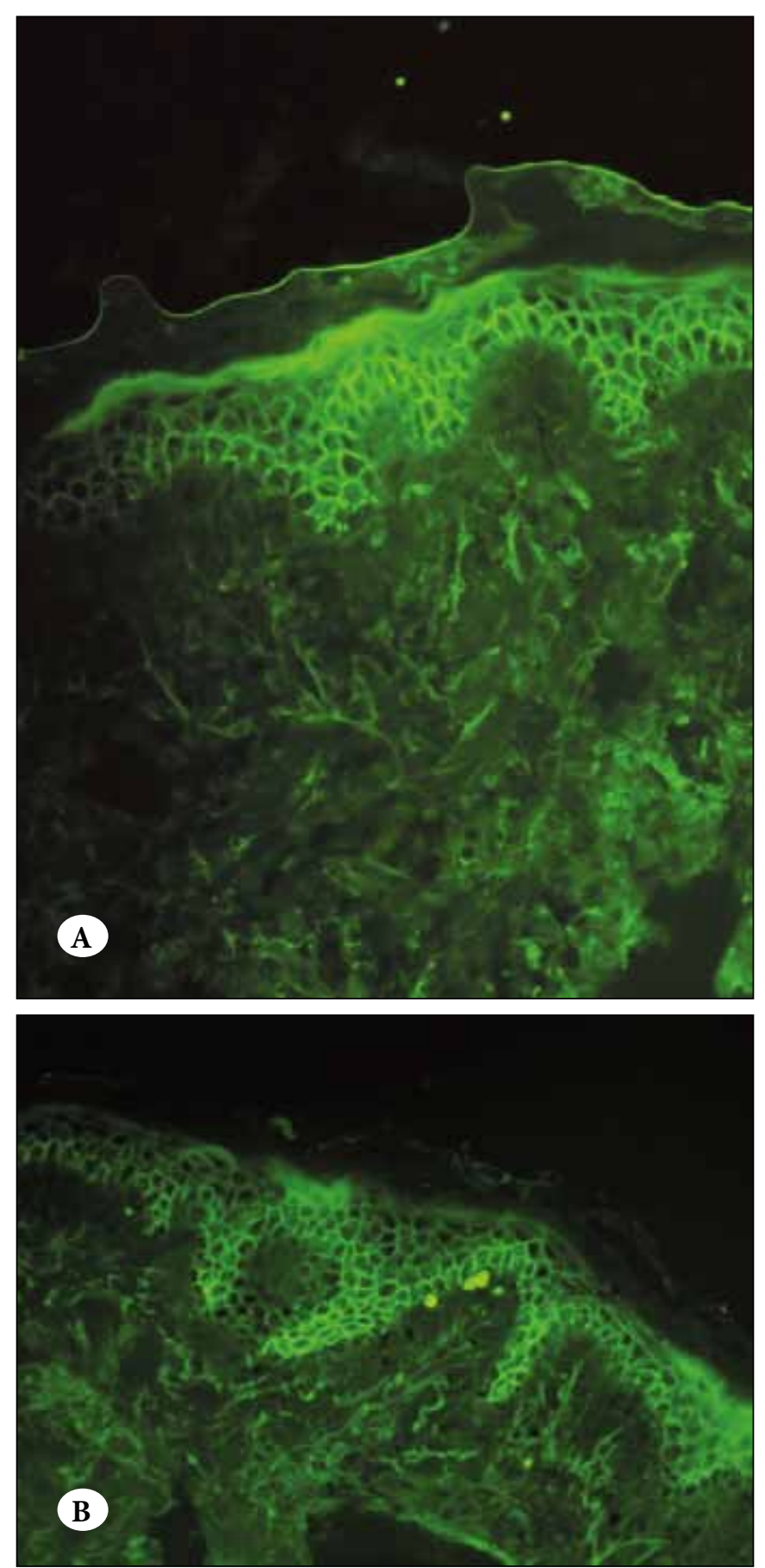

Figure 1: A) Intercellular IgG deposition in the epidermis in one of PV case (DIF, x20), B) Intercellular C3 deposition in the epidermis in one of PV case (DIF, x20).

Seven of 13 cases with clinical diagnosis of PF were diagnosed as PF (53.8\%) by histopathology and DIF microscopy. Histopathological examination revealed cleft formation and significant acantholysis in stratum granulosum of the epidermis and dermal perivascular lymphocytic infiltrate. DIF microscopy showed intercellular IgG and/ or C3 deposition in the epidermis in all PF cases (Figure $2 \mathrm{~A}, \mathrm{~B})$. The remaining 6 cases were diagnosed as pustular dermatitis in 3 cases (23.1\%), nonspecific superficial perivacular dermatitis in 2 cases (15.4\%), and psoriasis in 1 case $(7.7 \%)$.

Twenty-five of 66 cases with clinical diagnosis of BP were diagnosed as BP (37.9\%) by histopathology and DIF microscopy. Light microscopy revealed subepidermal clefting in epidermis and dermal perivascular eosinophils and lymphocytes. By DIF microscopy, linear IgG and/ or $\mathrm{C} 3$ deposition in the basement membrane zone of the epidermis were observed in all BP cases (Figure 3A,B). The remaining 41 cases were diagnosed as nonspecific superficial perivacular dermatitis in 22 cases (33.3\%), spongiotic dermatitis in 4 cases (6.1\%), drug eruption in 3 cases (4.5\%), pustular dermatitis in 3 cases (4.5\%), erythema multiforme in 2 cases (3\%), lymphocytic vasculitis in 2
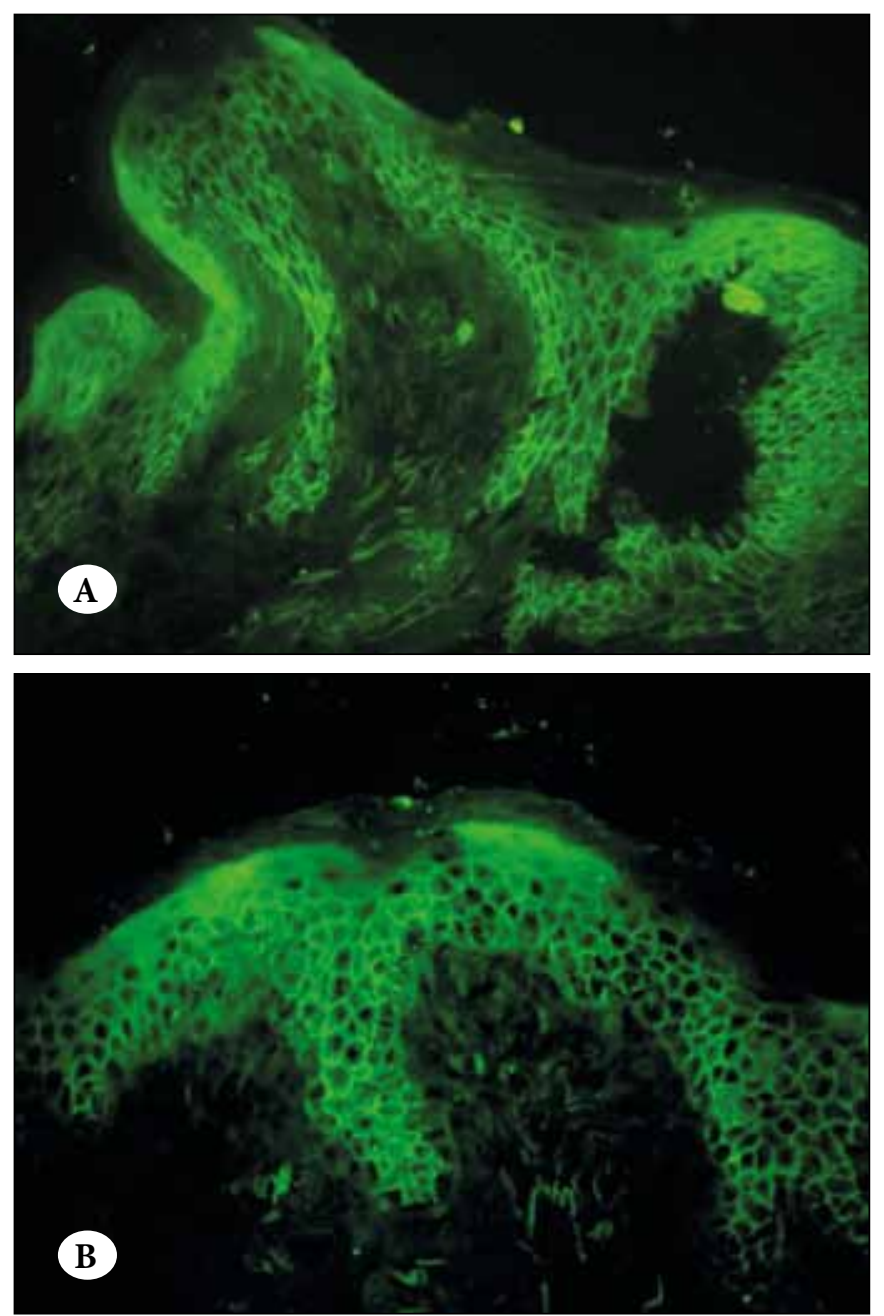

Figure 2: A) Intercellular IgG deposition in all levels of epidermis in PF (DIF, x20), B) Intercellular C3 deposition in all level of the epidermis in PF (DIF, $\mathrm{x} 20$ ). 

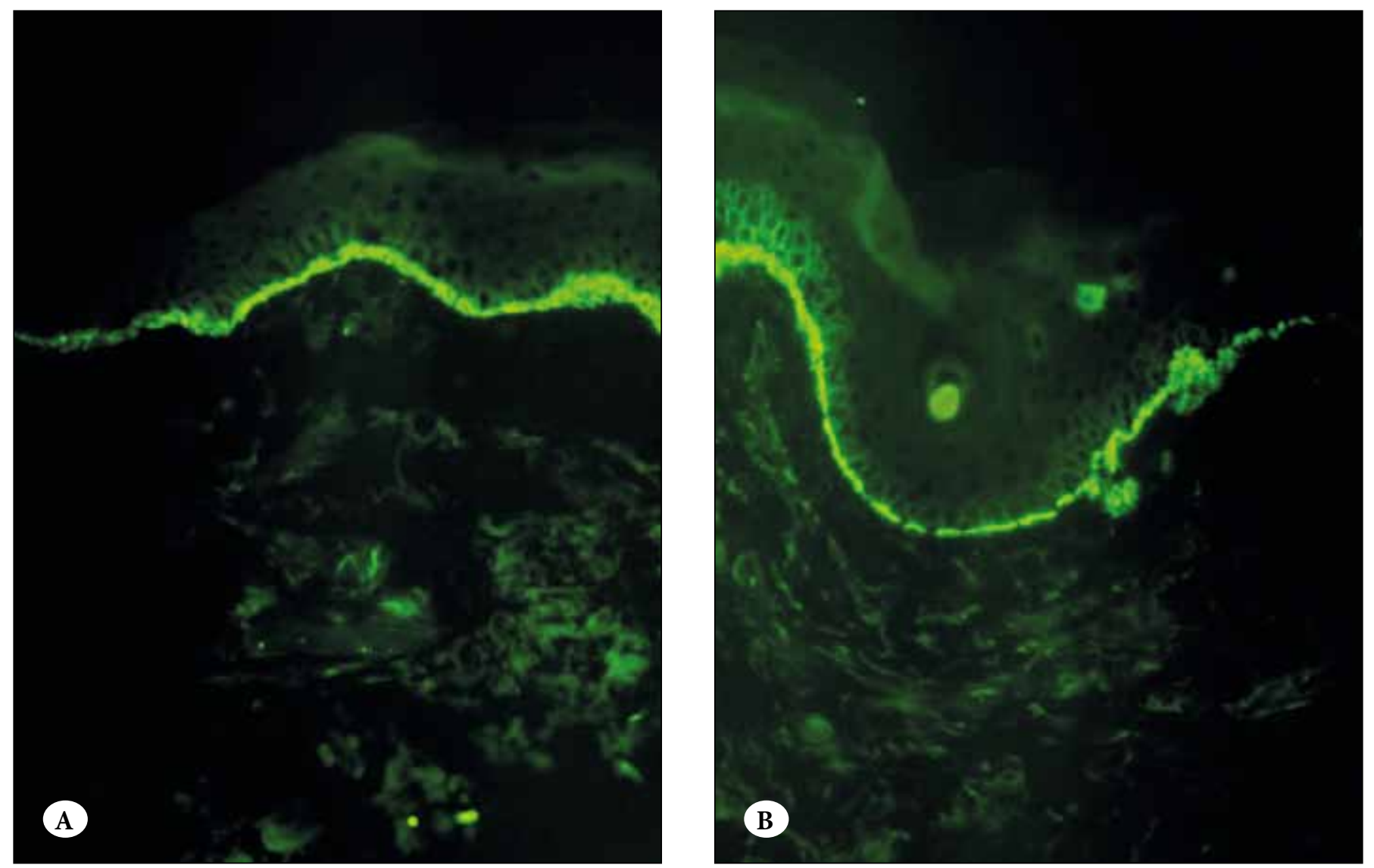

Figure 3: A) Linear IgG deposition in the basement membrane zone of the epidermis in BP (DIF, x20), B) Linear C3 deposition in the basement membrane zone of the epidermis in BP (DIF, x20).

cases (3\%), vasculitis in 2 case (3\%), lichen planus in 1 case (1.5\%), herpes virus infection in 1 case $(1.5 \%)$ and, LIGA in 1 case $(1.5 \%)$ which revealed linear IgA deposition in the basement membrane zone.

Only 3 of 58 cases with clinical diagnosis of DH were diagnosed as $\mathrm{DH}(5.2 \%)$ by histopathology and DIF microscopy. Histopathological examination revealed dermal papillary neutrophilic collections or microabcess formations and, subepidermal clefting. By DIF microscopy, granular IgA and/or C3 deposition in the basement membrane zone of the epidermis and/or papillary dermis were observed in all DH cases (Figure 4A,B). The remaining 55 cases were diagnosed as nonspecific superficial perivascular dermatitis in 30 cases $(51.7 \%)$, spongiotic dermatitis in 7 cases (12.1\%), lymphocytic vasculitis in 6 cases $(10.3 \%)$, pustular dermatitis in 5 cases $(8.6 \%)$, drug eruption in 2 cases (3.4\%), vasculitis in 2 cases (3.4\%), BP in 2 cases $(3.4 \%)$ and, erythema multiforme in 1 case $(1.7 \%)$.

Cases of limited numbers in our study were LIGA in 2 cases, GD in 1 case, EPB in 5 cases and, HH in 1 case. The percentage of accordance in these cases were $50 \%, 100 \%$, $40 \%$ and, $0 \%$, respectively.
The clinical and histopathological/DIF accordance for cases ranged from $0 \%$ to $100 \%$ (Kappa value $=0.29$ ). When the limited number of LIGA, GD, EPB and HH cases were excluded from the statistical analysis, agreement ranged from $5.2 \%$ to $58.8 \%$. In the majority of cases that no accordance was observed, the pattern of non-specific superficial perivascular dermatitis was mostly seen. In addition, drug eruption and spongiotic dermatitis were also observed.

\section{DISCUSSION}

Autoimmune vesiculobullous skin diseases are known to be morphologically heterogeneous like other inflammatory dermatoses. The differentiation between the entities is important for both treatment modalities and prognosis (1). The gold standard for definitive diagnosis is still the detection of autoantibodies by DIF microscopy (2).

In our study, we observed accordance in pemphigus groups including pemphigus vulgaris and pemphigus foliaceus (58.8\%, and 53.8\%, respectively). By light microscopy, cases of PV revealed suprabasal acantholysis and bullae formation as described previously $(4,5)$. In case of 

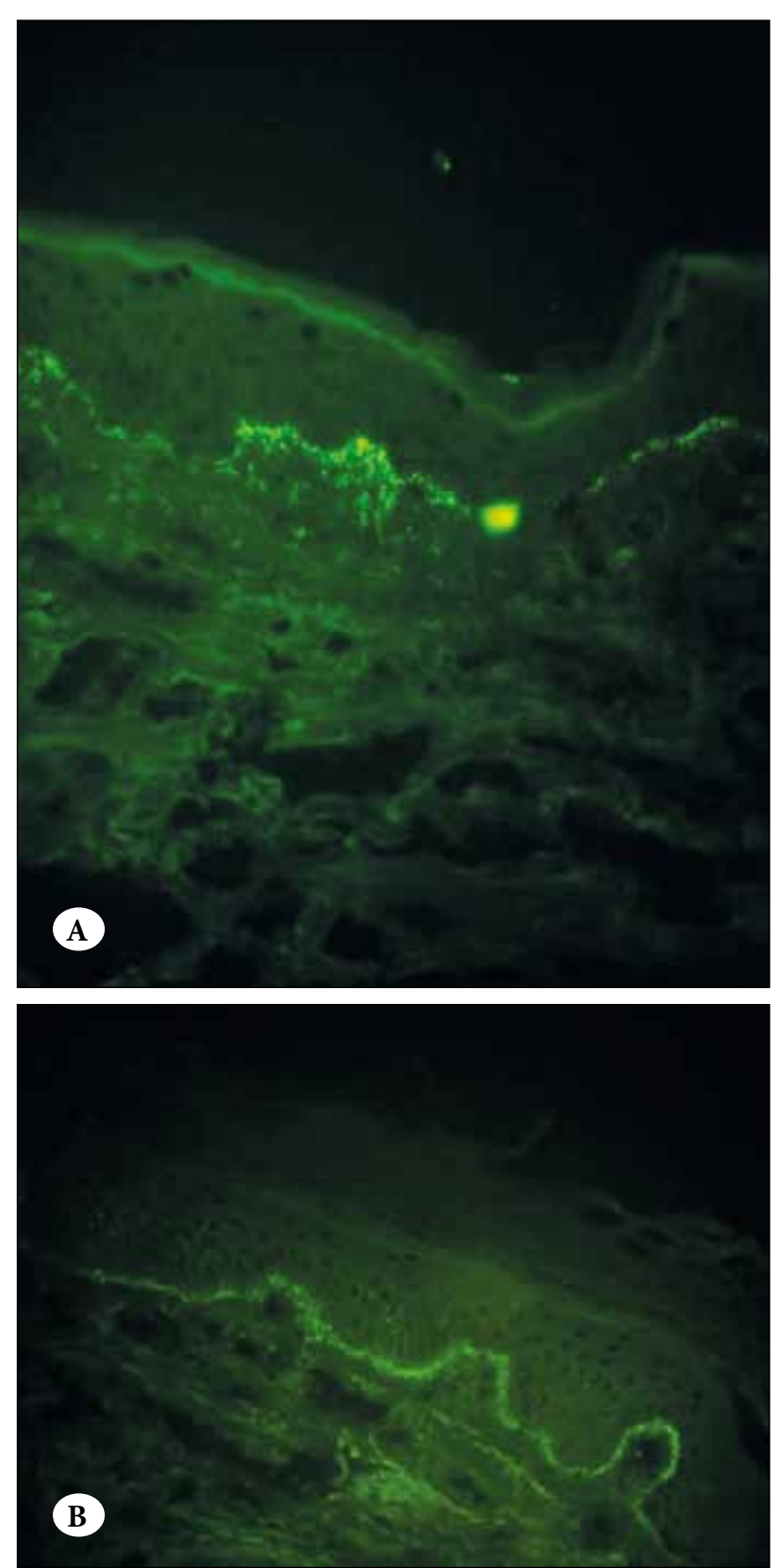

Figure 4: A) Granular IgA deposition in the basement membrane zone of the epidermis and/or papillary dermis in DH (DIF, x10), B) Granular C3 deposition in the basement membrane zone of the epidermis and/or papillary dermis in DH (DIF, x10).

suprabasal acantholysis, pemphigus vulgaris and HaileyHailey disease had been included in our histopathological differential diagnosis (2). DIF microscopy was very helpful in differentiating these entities.

DIF microscopy evaluate tissue for the presence of autoantibodies, complement, and fibrin. To obtain accurate results, it is important to take the biopsy sample for DIF microscopy from the appropriate site, to place it in the correct transport media, and to convey it to the laboratory without delay. Failure at any one of these points contributes to false negative results. Biopsy samples for DIF studies on blistering diseases should be taken from skin that appears normal, close to the edge of the blister. Inflamed areas are another potential cause of false negative DIF results. Biopsy specimens that only contain epidermis or exclusively lesional skin may yield false-negative results.

$\mathrm{BP}$ is the most common autoimmune subepidermal bullous disease characterized by antibodies against components of the hemidesmosome in epidermal basal cells $(6,7)$. We found moderate accordance (37.9\%) in cases with clinical diagnosis of BP. The remaining 41 cases that had no antibody deposition by DIF microscopy, were mostly diagnosed as nonspecific superficial perivacular dermatitis and spongiotic dermatitis. According to our results concerning BP, DIF microscopy seems to be a useful diagnostic method for definitive diagnosis. In a study of Libsker and Borradori (8), authors evaluated atypical variants of BP which were described by Geiss Steiner et al. (9). Author's view about these atypical variants was that the presence of circulating autoantibodies by either ELISA or indirect IF studies did not allow to make a diagnosis of $\mathrm{BP}$ if DIF microscopy is negative (8). This editorial paper stated that immunopathologic findings at DIF microscopy were very important to make definitive diagnosis of even atypical variants of $B P$.

Although DH was the second most common clinical diagnosis in our series, we found the lowest rates of accordance in cases of $\mathrm{DH}$ (5.2\%) if we excluded the limited number of LIGA, EPB, GH and HH cases. Only 3 of 58 cases with clinical diagnosis of $\mathrm{DH}$ were diagnosed as $\mathrm{DH}$ by histopathological and DIF findings. In a study of AlonsoLlamazares et al. (10), the authors reported the Mayo Clinic experience with patients with $\mathrm{DH}$ and evaluated gluten-sensitive enteropathy, autoimmune diseases and lymphoma associations. The authors also assessed the value of histopathologic finding in the diagnosis of $\mathrm{DH}$ and determined the sensitivity of immunofluorescence as a diagnostic test. They reported that $22 \%$ of the cases with DH showed nonspecific histopathological findings, and granular IgA deposition at the dermal-epidermal junction by DIF microscopy was considered to be pathognomonic of DH. We found nonspecific histopathological findings such as superficial perivascular dermatitis in biopsies with a clinical diagnosis of $\mathrm{DH}$ in $94.8 \%$ of patients. We also report a significantly lower than expected accordance compared with other DH series in the literature (11). The possible reason for this discordance may be due to 
pruritic papulovesicular eruptions of $\mathrm{DH}$ that evolved and disappeared rapidly. Another explanation for this discordance could be the inclusion of $\mathrm{DH}$ to clinical differential diagnosis by the clinicians in all pruritic skin diseases. Multiple biopsies could be taken at different times and DIF microscopy performed for the definitive diagnosis.

In our series, the overall clinical and histopathological/ DIF accordance for cases ranged from 0\% to 100\% (Kappa value $=0.29$ ). The $0 \%$ accordance rate was observed in a $\mathrm{HH}$ case which had negative DIF findings. This case was diagnosed as nonspecific perivascular dermatitis. The accordance of $100 \%$ was observed in GD that revealed epidermal acantholytic diskeratotic focus and had negative DIF findings. When the limited number of LIGA, GD, EPB and $\mathrm{HH}$ cases were excluded from the statistical analysis, accordance ranged from $5.2 \%$ to $58.8 \%$.

In conclusion, DIF microscopy has been shown to be the most useful technique for the final diagnosis of vesiculobullous diseases. DIF findings also should be correlated with histopathological features. Although our overall accordance was moderate, based on our results, we recommend DIF microscopy to be added to light microscopy for the definitive diagnosis of autoimmune blistering disease. Only light microscopic findings are not sufficient and we think that DIF is the gold standard.

\section{ACKNOWLEDGEMENT}

We would like to thank Professor Uğur Pabuççuoğlu for helping us during oral presentation of this study.

\section{REFERENCES}

1. Morrison LH: When to request immunofluorescence: Practical hints. Semin Cutan Med Surg 1999, 18: 36-42

2. Schmidt E, Zillikens D: Modern diagnosis of autoimmune blistering diseases. Autoimmun Rev 2010, 10: 84-89

3. Aoki V, Sousa JX, Fukumori LMI, Perigo AM, Freitas EL, Oliveira ZNP: Direct and indirect immunofluorescence. An Bras Dermatol 2010, 85: 490-500

4. Shinkuma S, Nishie W, Shibaki A, Sawamura D, Ito K, TsujiAbe Y, Natsuga K, Chan T, Amagai M, Shimizu H: Cutaneous pemphigus vulgaris with skin features similar to the classic mucocutaneous type: A case report and review of the literature. Clin Exp Dermatol 2008, 33: 724-728

5. Akman A, Uzun S, Alpsoy E: Immunopathologic features of pemphigus in the east Mediterranean Region of Turkey: A prospective study. Skinmed 2010, 8: 12-16

6. Ujiie H, Shibaki A, Nishie W, Shimizu H: What's new in bullous pemphigoid. J Dermatol 2010, 37: 194-204

7. Parker SRS, MacKelfresh J: Autoimmune blistering disease in the elderly. Clin Dermatol 2011, 29: 69-79

8. Lipsker D, Borradori L: "Bullous" pemphigoid: What are you? Urgent need of definitions and diagnostic criteria. Dermatology 2010, 221: 131-134

9. Geiss Steiner J, Trüeb RM, Kerl K, Mühleisen B, French LE, Hofbauer GFL: Ecthyma-gangrenosum-like bullous pemphigoid. Dermatology 2010, 221: 142-148

10. Alonso-Llamazares J, Gibson LE, Rogers III RS: Clinical, pathologic, and immunopathologic features of dermatitis herpetiformis: Review of the Mayo Clinic experience. Int J Dermatol 2007, 46: 910-919

11. Warren SJP, Cockerell CJ: Characterization of a subgroup of patients with dermatitis herpetiformis with nonclassical histologic features. Am J Dermatopathol 2002, 24: 305-308 